\title{
PERSEPSI MAHASISWA PROGRAM STUDI \\ PENDIDIKAN GURU SEKOLAH DASAR UNIVERSITAS WIDYA DHARMA TENTANG ETIKA MAHASISWA
}

\author{
${ }^{1}$ Bayu Purbha Sakti, S.Or., M.Pd \\ ${ }^{1}$ Fakultas Keguruan dan IImu Pendidikan, Universitas Widya Dharma \\ Alamat e-mail : 'bayups@unwidha.ac.id \\ ${ }^{2}$ Fembriani, S.Pd., M.Pd. \\ ${ }^{2}$ Fakultas Keguruan dan IImu Pendidikan, Universitas Widya Dharma \\ Alamat e-mail : ${ }^{2}$ fembriani@unwidha.ac.id
}

\begin{abstract}
This research is based on observation of researchers related to behavior and ethics in the student classroom of Primary School Teacher Education Study Program (PGSD) of Widya Dharma University. This research has purpose to know student perception of PGSD Study Program at Widya Dharma University about student ethics. This research is called descriptive research. The subject of this research is the student of Widya Dharma University PGSD Study Program. Data were collected by documentation and questionnaire tehniques. Data were analyzed by editing, coding, scoring, and making table. The result of this study are as follows; Most of the students of Widya Dharma University PGSD Study Program have positive perception toward student ethics. Most of the student already understand the rights, obligations, association, responsibility, dress, time, commitment, and prohibition in living ethics as a student of Widya Dharma University.
\end{abstract}

Keyword: PGSD Study Program, Student Ethics, Student Perception

\begin{abstract}
ABSTRAK
Penelitian ini dilatarbelakangi observasi peneliti berkaitan perilaku dan etika di ruang kelas mahasiswa Program Studi Pendidikan Guru Sekolah Dasar (PGSD) Universitas Widya Dharma. Penelitian ini memiliki tujuan untuk mengetahui persepsi mahasiswa Program Studi PGSD Universitas Widya Dharma tentang etika mahasiswa. Penelitian ini dinamakan penelitian deskripsi. Subjek penelitian ini adalah para mahasiswa Program Studi PGSD Universitas Widya Dharma. Data dikumpulkan dengan teknik dokumentasi dan angket. Data dianalisis dengan pengeditan, pengkodean, pemberian skor, dan pembuatan tabel. Hasil dari penelitian ini adalah sebagai berikut; Sebagian besar mahasiswa Program Studi PGSD Universitas Widya Dharma memiliki persepsi yang positif terhadap etika mahasiswa. Sebagian besar mahasiswa tersebut sudah memahami hak,
\end{abstract}


kewajiban, pergaulan, tanggung jawab, berpakaian, komitmen waktu, dan larangan dalam menjalani etika sebagai mahasiswa Universitas Widya Dharma.

Kata Kunci: Program Studi PGSD, Etika Mahasiswa, Persepsi Mahasiswa

\section{A. Pendahuluan}

Perguruan tinggi memiliki peranan terhadap tindakan yang dialami mahasiswa. Terdapat peranan yang dilakukan universitas di China. Seorang mahasiswa yang tak disebutkan namanya mengatakan kepada Beijing Times bahwa mahasiswa pria tak boleh menunjukkan ke publik membantu membawakan tas kekasih wanitanya (Febrida, 2016). Universitas swasta itu terletak di kota China Timur, Qingdao. Pihak kampus melarang mahasiswanya bergandengan tangan atau berpelukan di depan umum. Mahasiswa juga tak boleh berbagi makanan dalam satu piring di kantin, atau berbagi earphone. Aturan-aturan tersebut menjadi masalah di Qingdao.

Kasus tentang tindakan mahasiswi yang memberikan peran buruk terhadap universitas juga terjadi di Indonesia. Salah satu mahasiswi perguruan tinggi swasta (PTS) di Surabaya Timur. Mahasiswi tersebut cukup berani memutuskan terjun di bisnis pacar sewaan yang tergolong baru di Indonesia (Andriansyah, 2016). Mahasiswi asal Surabaya ini, membuka bisnis jasa pacar sewaan dengan mengajak mantan kakak kelasnya untuk mencari uang tambahan saat kuliah. Mahasiswi itu akan menawarkan pilihan gadis yang pintar dan cakap. Hal itu bertujuan agar pelanggan tidak canggung dan bisa berkomunikasi dengan baik. Untuk mencegah halhal negatif tersebut alangkah lebih baiknya diadakan pembentukan karakter mahasiswa yang lebih baik.

Berdasarkan observasi yang sudah dilakukan penulis di Bulan November 2016, maka terdapat perilaku mahasiswa yang belum sesuai dengan pedoman etika mahasiswa Universitas Widya Dharma. Oleh karena itu, penulis bertujuan mengadakan penelitian untuk mengetahui deskripsi etika para mahasiswa dan mahasiswi Program Studi Pendidikan Guru Sekolah Dasar. 
Pendas : Jurnal IImiah Pendidikan Dasar, ISSN Cetak : 2477-2143 ISSN Online : 2548-6950 Volume III Nomor 1, Juni 2018

Persepsi merupakan suatu proses yang didahului oleh proses penginderaan yaitu merupakan proses diterimanya stimulus oleh individu melalui alat indera (Walgito, 2010: 102). Persepsi adalah penafsiran suatu obyek, peristiwa atau informasi yang dilandasi oleh pengalaman hidup seseorang yang melakukan penafsiran itu (Rahmat, 2003: 16). Oleh karena itu persepsi dapat dikatakan sebagai hasil pikiran seseorang dari situasi tertentu. Dari uraian di atas dapat disimpulkan bahwa persepsi adalah penilaian terhadap suatu objek yang dipengaruhi oleh alat indera.

Etika adalah seperangkat prinsip moral yang menjadi pedoman perilaku seseorang (Sontani, 2016). Moral ini dibentuk oleh norma-norma sosial, praktikpraktik budaya, dan pengaruh agama. Etika mencerminkan keyakinan tentang segala sesuatu yang baik dan buruk dalam hal perilaku manusia.

Mahasiswa sebagai manusia yang beradab tentunya memiliki etika yang baik pula. Etika dan pergaulan mahasiswa sudah dijadikan peraturan di beberapa perguruan tinggi. Peraturan tersebut dibuat tentunya untuk menjadikan mahasiswa memiliki etika yang diharapkan oleh pihak perguruan tinggi. Berdasarkan Peraturan Rektor Universitas Negeri Yogyakarta Nomor : 03 Tahun 2009 tentang etika dan tata tertib pergaulan mahasiswa di kampus pasal 1 ayat 13 dijelaskan bahwa etika mahasiswa adalah normanorma yang perlu dilaksanakan oleh setiap mahasiswa dalam bersikap dan berperilaku sebagai upaya untuk mengokohkan visi dan misi UNY serta memperkuat sinergi sosial dan akademik di kampus UNY.

Permasalahan yang dialami mahasiswa berkaitan dengan etika, tata tertib, dan pergaulan sudah menjadi tanggung jawab pihak perguruan tinggi untuk menyelesaikannya. Berdasarkan Peraturan Rektor Universitas Gadjah Mada Nomor 711/P/SK/HT/2013 dijelaskan bahwa penyelidikan atas pelanggaran tata perilaku mahasiswa dilakukan oleh Komite Etik. Komite Etik ditugaskan oleh 
Pendas : Jurnal IImiah Pendidikan Dasar, ISSN Cetak : 2477-2143 ISSN Online : 2548-6950

Volume III Nomor 1, Juni 2018

pimpinan universitas untuk menegakkan, menyelidiki, dan menyampaikan rekomendasi penyelesaian masalah tata perilaku mahasiswa.

\section{B. Landasan Teori}

\section{Berdasarkan}

Keputusan

Rektor Universitas Widya Dharma Klaten nomor

185/a.51.01/Unwidha/III/2014 maka etika pergaulan dalam lingkungan universitas didasarkan atas azasazas kekeluargaan serta menjunjung tinggi keselarasan, keharmonisan, dan keseimbangan sesuai dengan pandangan hidup Pancasila dan norma-norma yang berlaku dalam masyarakat. Harapan pihak perguruan tinggi terhadap penerapan etika mahasiswa adalah perilaku mahasiswa yang beretika baik diimplementasikan dalam pelaksanaan di dalam maupun di luar perguruan tinggi. Harapannya adalah mahasiswa mampu menjadi model karakter yang baik di tengah masyarakat.

Program studi pendidikan guru sekolah dasar merupakan program studi (prodi) yang mengarahkan mahasiswa untuk memiliki keahlian di bidang sekolah dasar. Berdasarkan Peraturan Menteri Pendidikan Nasional Nomor 16 Tahun 2007 tanggal 4 Mei 2007 disebutkan bahwa guru pada SD/MI harus memiliki kualifikasi akademik pendidikan minimum Diploma Empat (D-IV) atau Sarjana (S1) dalam bidang pendidikan SD/MI (D-IV/S1 PGSD/PGMI) atau psikologi yang diperoleh dari program studi yang terakreditasi. Dari penjelasan kualifikasi standar guru tersebut maka diharapkan guru sekolah dasar memiliki fungsi dan keahlian dalam menangani anak usia sekolah dasar.

\section{Metode Penelitian}

Pendekatan yang digunakan dalam penelitian ini adalah pendekatan penelitian survey deskripsi. Penelitian ini memusatkan perhatian pada masalah-masalah atau fenomena yang bersifat aktual pada saat penelitian dilakukan, menggambarkan fakta-fakta tentang masalah yang diselidiki.

Subyek penelitian ini adalah mahasiswa S1 Program Studi Pendidikan Guru Sekolah Dasar. Dalam penelitian ini digunakan 
Pendas : Jurnal IImiah Pendidikan Dasar, ISSN Cetak : 2477-2143 ISSN Online : 2548-6950 Volume III Nomor 1, Juni 2018

pengambilan sampel semua mahasiswa S1 Program Studi Pendidikan Guru Sekolah Dasar angkatan 2016 kelas reguler A dan B.

Pengumpulan data pada penelitian ini dilakukan dengan menggunakan kuesioner dan dokumentasi. Peneliti menyusun instrumen penelitian dengan mengkategorikan berdasarkan pasal-pasal yang terdapat dalam pedoman etika mahasiswa Universitas Widya Dharma Klaten. Pasal-pasal tersebut kemudian dibuat sebuah angket. Penyusunan instrumen penelitian mempertimbangkan kisi-kisi tentang hak, kewajiban, pergaulan, tanggung jawab, berpakaian, komitmen waktu, dan larangan.

Penyusunan kisi-kisi tersebut dibuat sesuai pasal-pasal yang terdapat dalam pedoman etika mahasiswa Universitas Widya Dharma Klaten. Adapun penjelasan pasal-pasal tersebut yaitu:

1. Pasal 8 mengenai hak,

2. Pasal 9 mengenai kewajiban,

3. Pasal 10 mengenai pergaulan,

4. Pasal 11 mengenai tanggung jawab,
5. Pasal 12 mengenai berpakaian,

6. Pasal 13 mengenai komitmen waktu, dan

7. Pasal 17 mengenai larangan.

Tahapan penyajian data dalam penelitian ini meliputi editing, coding, scoring, dan making table. Peneliti perlu melakukan pengecekan atau pengoreksian data yang telah terkumpul. Tujuan dari Editing yaitu untuk menghilangkan kesalahankesalahan yang terdapat pada pencatatan di lapangan dan bersifat koreksi. Editing dalam penelitian ini yaitu mengecek atau mengoreksi kuesioner penelitian yang telah disebar.

Peneliti perlu melakukan pemberian kode-kode pada tiaptiap data yang termasuk dalam katagori yang sama. Kode adalah isyarat yang dibuat dalam bentuk angka atau huruf yang memberikan petunjuk atau identitas pada suatu informasi atau data yang akan dianalisis. Pengkodean (coding) dalam penelitian ini yaitu memberikan kode terhadap kuesioner yang akan dianalisis, dari 52 kuesioner yang 
Pendas : Jurnal IImiah Pendidikan Dasar, ISSN Cetak : 2477-2143 ISSN Online : 2548-6950

Volume III Nomor 1, Juni 2018

telah disebar masing-masing kuesioner diberikan angka 1-55 yang membedakan jawaban dari tiap responden.

Peneliti perlu melakukan pemberian skor (scoring) menggunakan skala Guttman yang merupakan salah satu cara untuk menentukan skor. Kriteria penilaian ini digolongkan dalam dua tingkatan dengan penilaian yaitu jawaban ya diberi skor 1 dan jawaban tidak diberi skor 0 .

Tabulasi merupakan tabeltabel yang dibuat dan berisi data kode sesuai dengan analisis yang dibutuhkan. Peneliti melakukan tabulasi memerlukan ketelitian agar tidak terjadi kesalahan. Tabulasi dalam penelitian ini yaitu jawaban dari kuesioner yang telah disebar dimasukkan ke dalam tabel sesuai dengan analisis contohnya tabulasi karakteristik responden yang meliputi ruang kelas.

Teknik pengolahan data yang digunakan adalah teknik pengolahan data deskriptif untuk mendeskripsikan variabel penelitian dalam pengukuran dan tidak menggunakan statistik inferensial karena tidak ada hipotesis dalam penelitian ini. Software yang digunakan untuk menghitung data dalam penelitian ini adalah Microsoft Office Excell 2007. Persentase untuk setiap kemungkinan jawaban diperoleh dari membagi frekuensi yang diperoleh dengan jumlah sampel, kemudian dikalikan $100 \%$.

\section{Hasil dan Pembahasan}

Hasil penelitian dan pembahasan disusun mengacu pada kisi-kisi instrumen penelitian yaitu hak, kewajiban, pergaulan, tanggung jawab, berpakaian, komitmen waktu, dan larangan. Kisikisi tersebut dibuat sesuai pasalpasal yang terdapat dalam pedoman etika mahasiswa Universitas Widya Dharma Klaten.

1. Hak mahasiswa

Tabel 1. Tabel Hak Mahasiswa PGSD

\begin{tabular}{|c|c|c|c|c|c|}
\hline No & Kelas & f0 & $f 1$ & $p 0$ & $p 1$ \\
\hline & A & 37 & 275 & 11,9 & 88,1 \\
\hline & B & 22 & 342 & 6,04 & 94 \\
\hline \multicolumn{2}{|c|}{ Jumlah } & 59 & 617 & 8,73 & 91,3 \\
\hline
\end{tabular}

Dari tabel di atas terdapat hasil analisis frekuensi menunjukkan 
Pendas : Jurnal Ilmiah Pendidikan Dasar, ISSN Cetak : 2477-2143 ISSN Online : 2548-6950

Volume III Nomor 1, Juni 2018

hasil jawaban dari kelas A dan B. Para mahasiswa di kelas A memberikan jawaban dalam menyetujui kuesioner hak mahasiswa dengan jumlah 275. Para mahasiswa di kelas B memberikan jawaban terbanyak dalam menyetujui kuesioner hak mahasiswa dengan jumlah 342 . Walaupun ada 59 jawaban yang menyangkal kuesioner hak mahasiswa, tetapi secara keseluruhan hasil jawaban dari kuesioner ini menunjukkan hasil yang positif dengan jumlah 617 .

Hasil analisis persentase mengenai hak mahasiswa dapat diketahui sebagai berikut. Kedua hasil persentase di kelas $A$ dan $B$ menunjukkan hasil dimana jawaban ya atau menyetujui sesuai isi dari kuesioner adalah yang paling dominan. Hasil persentase yang didapatkan di kelas A sebanyak 88 persen. Hasil persentase yang didapatkan di kelas B sebanyak 94 persen. Apabila hasil persentase tersebut ditotal maka akan didapatkan 91 persen. Hasil tersebut telah menunjukkan hasil yang positif karena para mahasiswa PGSD memahami hak yang harus dilakukan sebagai bagian dari warga Universitas Widya Dharma.

2. Kewajiban mahasiswa

Tabel 2. Tabel Kewajiban Mahasiswa PGSD

\begin{tabular}{|c|c|c|c|c|c|}
\hline No & Kelas & f0 & f1 & p0 & p1 \\
\hline 1 & A & 2 & 286 & 0,69 & 99,3 \\
\hline 2 & B & 1 & 335 & 0,3 & 99,7 \\
\hline \multicolumn{2}{|c|}{ Jumlah } & 3 & 621 & 0,48 & 99,5 \\
\hline
\end{tabular}

Dari tabel di atas terdapat hasil analisis frekuensi menunjukkan hasil jawaban dari kelas $A$ dan $B$. Para mahasiswa di kelas A memberikan jawaban dalam menyetujui kuesioner kewajiban mahasiswa dengan jumlah 286. Para mahasiswa di kelas B memberikan jawaban terbanyak dalam menyetujui kuesioner kewajiban mahasiswa dengan jumlah 335. Walaupun ada 3 jawaban yang menyangkal kuesioner kewajiban mahasiswa, tetapi secara keseluruhan hasil jawaban dari kuesioner ini menunjukkan hasil yang positif dengan jumlah 621.

Hasil analisis persentase mengenai kewajiban mahasiswa dapat diketahui sebagai berikut. Kedua hasil persentase di kelas $A$ 
Pendas : Jurnal Ilmiah Pendidikan Dasar, ISSN Cetak : 2477-2143 ISSN Online : 2548-6950 Volume III Nomor 1, Juni 2018

dan B menunjukkan hasil dimana jawaban ya atau menyetujui sesuai isi dari kuesioner adalah yang paling dominan. Hasil persentase yang didapatkan di kelas A sebanyak 99 persen. Hasil persentase yang didapatkan di kelas B sebanyak 99 persen. Apabila hasil persentase tersebut ditotal maka akan didapatkan 99 persen. Hasil tersebut telah menunjukkan hasil yang positif karena para mahasiswa PGSD memahami kewajiban yang harus dilaksanakan sebagai penerus generasi Universitas Widya Dharma.

3. Pergaulan mahasiswa

Tabel 3. Tabel Pergaulan Mahasiswa PGSD

\begin{tabular}{|c|c|c|c|c|c|}
\hline No & Kelas & f0 & f1 & p0 & p1 \\
\hline 1 & A & 1 & 71 & 1,39 & 98,6 \\
\hline 2 & B & 1 & 83 & 1,19 & 98,8 \\
\hline \multicolumn{2}{|c|}{ Jumlah } & 2 & 154 & 1,28 & 98,7 \\
\hline
\end{tabular}

Dari tabel di atas terdapat hasil analisis frekuensi menunjukkan hasil jawaban dari kelas $A$ dan $B$. Para mahasiswa di kelas A memberikan jawaban dalam menyetujui kuesioner pergaulan mahasiswa dengan jumlah 71. Para mahasiswa di kelas $\mathrm{B}$ memberikan jawaban

terbanyak

dalam menyetujui kuesioner pergaulan mahasiswa dengan jumlah 83. Walaupun ada 2 jawaban yang menyangkal kuesioner pergaulan mahasiswa, tetapi secara keseluruhan hasil jawaban dari kuesioner ini menunjukkan hasil yang positif dengan jumlah 154 .

Hasil analisis persentase mengenai pergaulan mahasiswa dapat diketahui sebagai berikut. Kedua hasil persentase di kelas $A$ dan $B$ menunjukkan hasil dimana jawaban ya atau menyetujui sesuai isi dari kuesioner adalah yang paling dominan. Hasil persentase yang didapatkan di kelas A sebanyak 98 persen. Hasil persentase yang didapatkan di kelas B sebanyak 98 persen. Apabila hasil persentase tersebut ditotal maka akan didapatkan 98 persen. Hasil tersebut telah menunjukkan hasil yang positif karena para mahasiswa PGSD memahami pergaulan yang dijalani sesuai norma dan aturan.

4. Tanggung jawab mahasiswa Tabel 4. Tanggung Jawab Mahasiswa PGSD

\begin{tabular}{|l|l|l|l|l|l|}
\hline No & Kelas & f0 & f1 & p0 & p1 \\
\hline 1 & A & 2 & 70 & 2,78 & 97,2 \\
\hline
\end{tabular}


Pendas : Jurnal Ilmiah Pendidikan Dasar, ISSN Cetak : 2477-2143 ISSN Online : 2548-6950 Volume III Nomor 1, Juni 2018

\begin{tabular}{|l|l|l|l|l|l|}
\hline 2 & B & 1 & 83 & 1,19 & 98,8 \\
\hline Jumlah & 3 & 153 & 1,92 & 98,1 \\
\hline
\end{tabular}

Dari tabel di atas terdapat hasil analisis frekuensi menunjukkan hasil jawaban dari kelas A dan B. Para mahasiswa di kelas A memberikan jawaban dalam menyetujui kuesioner tanggung jawab mahasiswa dengan jumlah 70. Para mahasiswa di kelas B memberikan jawaban terbanyak dalam menyetujui kuesioner tanggung jawab mahasiswa dengan jumlah 83. Walaupun ada 3 jawaban yang menyangkal kuesioner tanggung jawab mahasiswa, tetapi secara keseluruhan hasil jawaban dari kuesioner ini menunjukkan hasil yang positif dengan jumlah 153.

Hasil analisis persentase mengenai tanggung jawab mahasiswa dapat diketahui sebagai berikut. Kedua hasil persentase di kelas A dan B menunjukkan hasil dimana jawaban ya atau menyetujui sesuai isi dari kuesioner adalah yang paling dominan. Hasil persentase yang didapatkan di kelas A sebanyak 97 persen. Hasil persentase yang didapatkan di kelas B sebanyak 98 persen.
Apabila hasil persentase tersebut ditotal maka akan didapatkan 98 persen. Hasil tersebut telah menunjukkan hasil yang positif karena para mahasiswa PGSD memahami tanggung jawab dalam menghadapi permasalahan yang ada di perkuliahan.

5. Berpakaiannya mahasiswa

Tabel 5. Tabel Berpakaiannya Mahasiswa PGSD

\begin{tabular}{|c|c|c|c|c|c|}
\hline No & Kelas & f0 & f1 & p0 & p1 \\
\hline 1 & A & 0 & 96 & 0 & 100 \\
\hline 2 & B & 0 & 112 & 0 & 100 \\
\hline \multicolumn{2}{|c|}{ Jumlah } & 0 & 208 & 0 & 100 \\
\hline
\end{tabular}

Dari tabel di atas terdapat hasil analisis frekuensi menunjukkan hasil jawaban dari kelas A dan B dimana para mahasiswa tidak menemui kendala dalam berpakaian. Para mahasiswa di kelas A memberikan jawaban dalam menyetujui

kuesioner berpakaiannya mahasiswa dengan jumlah 96. Para mahasiswa di kelas B memberikan jawaban terbanyak dalam menyetujui kuesioner berpakaiannya mahasiswa dengan jumlah 112. Secara keseluruhan hasil jawaban dari kuesioner ini 
Pendas : Jurnal IImiah Pendidikan Dasar, ISSN Cetak : 2477-2143 ISSN Online : 2548-6950

Volume III Nomor 1, Juni 2018

menunjukkan hasil yang positif dengan jumlah 208.

Hasil analisis persentase tentang berpakaiannya mahasiswa dapat diketahui sebagai berikut. Kedua hasil persentase di kelas $A$ dan $B$ menunjukkan hasil dimana jawaban ya atau menyetujui sesuai isi dari kuesioner adalah yang paling dominan. Hasil persentase yang didapatkan di kelas A dan B sebanyak 100 persen. Hasil tersebut telah menunjukkan hasil yang positif karena para mahasiswa PGSD memahami cara berpakaian yang telah dijalani sejak kecil.

6. Komitmen waktu mahasiswa Tabel 6. Tabel Komitmen Waktu Mahasiswa PGSD

\begin{tabular}{|c|c|c|c|c|c|}
\hline No & Kelas & f0 & f1 & $\mathrm{p} 0$ & $\mathrm{p} 1$ \\
\hline 1 & $A$ & 1 & 143 & 0,69 & 99,3 \\
\hline 2 & $B$ & 1 & 167 & 0,6 & 99,4 \\
\hline & Jumlah & 2 & 310 & 0,64 & 99,4 \\
\hline
\end{tabular}

Dari tabel di atas terdapat hasil analisis frekuensi menunjukkan hasil jawaban dari kelas A dan B. Para mahasiswa di kelas A memberikan jawaban dalam menyetujui kuesioner komitmen waktu mahasiswa dengan jumlah 143. Para mahasiswa di kelas B memberikan jawaban terbanyak dalam menyetujui kuesioner komitmen waktu mahasiswa dengan jumlah 167. Walaupun ada 2 jawaban yang menyangkal kuesioner komitmen waktu mahasiswa, tetapi secara keseluruhan hasil jawaban dari kuesioner ini menunjukkan hasil yang positif dengan jumlah 310 .

Hasil analisis persentase mengenai komitmen waktu mahasiswa dapat diketahui sebagai berikut. Kedua hasil persentase di kelas $A$ dan $B$ menunjukkan hasil dimana jawaban ya atau menyetujui sesuai isi dari kuesioner adalah yang paling dominan. Hasil persentase yang didapatkan di kelas A sebanyak 99 persen. Hasil persentase yang didapatkan di kelas B sebanyak 99 persen. Apabila hasil persentase tersebut ditotal maka akan didapatkan 99 persen. Hasil tersebut telah menunjukkan hasil yang positif karena para mahasiswa PGSD memahami komitmen waktu dalam menjalani kegiatan perkuliahan.

7. Larangannya mahasiswa

Tabel 7. Tabel Larangannya Mahasiswa PGSD 
Pendas : Jurnal IImiah Pendidikan Dasar, ISSN Cetak : 2477-2143 ISSN Online : 2548-6950

Volume III Nomor 1, Juni 2018

\begin{tabular}{|c|c|c|c|c|c|}
\hline No & Kelas & f0 & f1 & p0 & p1 \\
\hline 1 & A & 1 & 335 & 0,3 & 99,7 \\
\hline 2 & B & 1 & 391 & 0,26 & 99,7 \\
\hline \multicolumn{2}{|c|}{ Jumlah } & 2 & 726 & 0,27 & 99,7 \\
\hline
\end{tabular}

Dari tabel di atas terdapat hasil analisis frekuensi menunjukkan hasil jawaban dari kelas A dan B. Para mahasiswa di kelas A memberikan jawaban dalam menyetujui kuesioner larangannya mahasiswa dengan jumlah 335. Para mahasiswa di kelas B memberikan jawaban terbanyak dalam menyetujui kuesioner larangannya mahasiswa dengan jumlah 391. Walaupun ada 2 jawaban yang menyangkal kuesioner larangannya mahasiswa, tetapi secara keseluruhan hasil jawaban dari kuesioner ini menunjukkan hasil yang positif dengan jumlah 726 .

Hasil analisis persentase mengenai larangannya mahasiswa dapat diketahui sebagai berikut. Kedua hasil persentase di kelas $\mathrm{A}$ dan B menunjukkan hasil dimana jawaban ya atau menyetujui sesuai isi dari kuesioner adalah yang paling dominan. Hasil persentase yang didapatkan di kelas A sebanyak 99

persen. Hasil persentase yang didapatkan di kelas B sebanyak 99 persen. Apabila hasil persentase tersebut ditotal maka akan didapatkan 99 persen. Hasil tersebut telah menunjukkan hasil yang positif karena para mahasiswa PGSD memahami larangan yang telah diterapkan.

Peneliti membahas total dari 7 pasal yang terdapat dalam pedoman etika mahasiswa Universitas Widya Dharma menjadi item atau kisi-kisi instrumen dalam penelitian ini. Pembahasan dari ketujuh pasal yang termuat dalam pedoman etika mahasiswa Universitas Widya Dharma Klaten akan menjadi jawaban dari pemasalahan penelitian ini.

Tabel 8. Tabel Persepsi Mahasiswa PGSD Unwidha terhadap Etika Mahasiswa

\begin{tabular}{|c|c|c|c|c|c|}
\hline No & Kelas & f0 & f1 & p0 & p1 \\
\hline 1 & A & 44 & 1276 & 3,33 & 96,7 \\
\hline 2 & B & 27 & 1513 & 1,75 & 98,2 \\
\hline \multicolumn{2}{|c|}{ Jumlah } & 71 & 2789 & 2,48 & 97,5 \\
\hline
\end{tabular}

Tabel 8 menjelaskan keterangan bahwa data kuesioner menunjukkan hasil jawaban persepsi mahasiswa Program Studi 
Pendas : Jurnal IImiah Pendidikan Dasar, ISSN Cetak : 2477-2143 ISSN Online : 2548-6950

Volume III Nomor 1, Juni 2018

Pendidikan Guru Sekolah Dasar Universitas Widya Dharma terhadap etika mahasiswa. Hasil analisis frekuensi menunjukkan hasil jawaban dari kelas $\mathrm{A}$ dan $\mathrm{B}$ dimana para mahasiswa di kelas A memberikan jawaban terbanyak dalam menyangkal dengan jumlah 44. Namun secara keseluruhan, hasil jawaban dari kuesioner persepsi mahasiswa ini menunjukkan hasil yang positif dengan jumlah 2789.

Hasil analisis persentase mengenai persepsi mahasiswa Program Studi PGSD Unwidha terhadap etika mahasiswa dapat diketahui sebagai berikut. Hasil persentase yang didapatkan di kelas A sebanyak 96 persen. Hasil persentase yang didapatkan di kelas B sebanyak 97 persen. Kedua hasil tersebut menunjukkan hasil dimana jawaban ya atau menyetujui sesuai isi dari kuesioner adalah yang paling dominan. Apabila hasil persentase tersebut ditotal maka akan didapatkan 97 persen. Hasil tersebut telah menunjukkan hasil yang positif.

\section{E. Kesimpulan}

Peneliti memberikan kesimpulan penelitian bahwa sebagian besar mahasiswa Program Studi Pendidikan Guru Sekolah Dasar Universitas Widya Dharma memiliki persepsi yang positif terhadap etika mahasiswa. Sebagian besar mahasiswa tersebut sudah memahami hak, kewajiban, pergaulan, tanggung jawab, berpakaian, komitmen waktu, dan larangan dalam menjalani etika sebagai mahasiswa Universitas Widya Dharma. Sebagian besar mahasiswa tersebut memiliki hasil yang positif terhadap pemahaman ketujuh komponen dari bagian kuesioner.

\section{DAFTAR PUSTAKA}

Andriansyah, M. (2016). Mahasiswi psikologi jadi pacar sewaan buat semangati para jomblo. https://www.merdeka.com/peristi wa/mahasiswi-psikologi-jadipacar-sewaan-buat-semangatipara-jomblo.html. Artikel diunduh pada tanggal 7 Desember 2016.

Febrida, M. (2016). Mahasiswa di kampus ini tak boleh bergandengan tangan http://health.liputan6.com/read/26 42298/mahasiswa-di-kampus-initak-boleh-bergandengan-tangan. 
Pendas : Jurnal Ilmiah Pendidikan Dasar, ISSN Cetak : 2477-2143 ISSN Online : 2548-6950

Volume III Nomor 1, Juni 2018

Artikel diunduh pada tanggal 7 Desember 2016.

Pratikno. (2013). Tata Perilaku Mahasiswa. Yogyakarta: Universitas Gadjah Mada.

Rahmat, J. (2003). Psikologi Komunikasi. Bandung : Remaja Rosdakarya.

Sontani, T. (2016). Pengertian etika. http://www.sridianti.com/pengertia n-etika.html. Artikel diunduh pada tanggal 15 Desember 2016.

Sudibyo, B. (2007). Peraturan Menteri Pendidikan Nasional No.
16 Tahun 2007 tentang Standar Kualifikasi dan Kompetensi Guru. Jakarta: Departemen Pendidikan Nasional.

Triyono. (2014). Pedoman Etika Mahasiswa. Klaten: Universitas Widya Dharma.

Wahab, R. (2009). Etika dan Tata Tertib Pergaulan Mahasiswa di Kampus. Yogyakarta: Universitas Negeri Yogyakarta.

Walgito, B. (2010). Pengantar Psikologi Umum. Yogyakarta: Penerbit Andi. 